\title{
John's Apocalypse: Dynamic word-images for a new world
}

Author:

Sergio Rosell ${ }^{1,2}$

\section{Affiliations:}

${ }^{1}$ Department New

Testament, Seminario

Evangélico Unido de

Teología, Spain

${ }^{2}$ Faculty of Theology, University of Pretoria, South Africa

Note:

Dr Sergio Rosell is participating as a research associate of Prof. Dr Andries G. van Aarde, Honorary Professor at the Faculty of Theology of the University of Pretoria, South Africa.

Correspondence to:

Sergio Rosell

email:

sergio.rosell@centroseut.org

Postal address:

Seminario Evangélico

Unido de Teología, Apdo.

de Correos 7, $28280 \mathrm{EI}$

Escorial, Spain

Dates:

Received: 20 Apr. 2010

Accepted: 22 June 2010

Published: 07 June 2011

How to cite this article: Rosell, S., 2011, 'John's Apocalypse: Dynamic word-images for a new world', HTS Teologiese Studies/Theological Studies 67(1), Art. \#832, 5 pages. DOI: $10.4102 /$ hts.v67i1.832

(C) 2011. The Authors. Licensee: OpenJournals Publishing. This work is licensed under the Creative Commons Attribution License.
The aim of the article is to investigate the function of the symbols and images in the Apocalypse of John. Its aim is to focus on the 'mental scenarios' readers are bringing to the text, rather than on John's supposed lack of ability to convey his message. The article discusses both the symbolic or iconographic and the evocative power within the historical situation which the author of the Apocalypse addresses. The article's intention is to show how John reveals an alternative way of understanding history through the use of his particular imagery, aided by film theory tools and based on previous work that had perceived the Apocalypse's 'theatrical' nature, in order to discover John's use of images, their function and the new world he aims to portray.

'Our visions, stories and utopias are not only aesthetic, they engage us'.

(Amos Wilder)

\section{Introduction}

\section{Revelation and the problem of its interpretation}

A brief glance at the history of the interpretation of the Apocalypse reveals a complex book, sealed for some, incomprehensible to others. No wonder part of the church struggled to accept it in the canon for some time. Dionysius, bishop of Alexandria, spoke of those who had abandoned its reading whilst admitting his own struggle:

But I could not venture to reject the book, as many brethren hold it in high esteem. But I suppose that it is beyond my comprehension, and that there is a certain concealed and more wonderful meaning in every part. For if I do not understand I suspect that a deeper sense lies beneath the words. I do not measure and judge them by my own reason, but leaving the more to faith I regard them as too high for me to grasp. And I do not reject what I cannot comprehend, but rather wonder because I do not understand it.

(Eusebius, Ecclesiastical History 7.25.4)

Some Reformation leaders likewise found it difficult: Luther complained he could not find Christ amid its pages, while Calvin wrote commentaries to all books of the New Testament except Revelation. Contemporary readers appear no different. Some conclude that it is a rather 'scary book' or the 'curious record of the visions of a drug addict' (Shaw 1933:73). ${ }^{1}$

Much of the problem lies in understanding the function of its symbols and images, and the mental scenarios we bring to the text, rather than in John's supposed lack of ability to convey his message. ${ }^{2}$ I suggest that we pay attention both to the symbolic or iconographic and to its evocative power within the historical situation that John addresses; for however visionary Revelation is, 'it does not operate in a symbolic universe apart from the world of actual, social relations' (Thompson 1990:95).

Aided by film theory tools and based on previous work that had perceived Revelation's 'theatrical nature' (Brewer 1952:228), my purpose is to show how John reveals an alternative way of understanding history through the use of his particular imagery. ${ }^{3}$ This way, although only briefly stated, we will be in a better position to discover John's use of his images, their function and the new world he aims to portray.

1.Holtzmann (1991:539-540) thought Revelation was a typical apocalyptic text where 'unadulterated Judaism and fully developed Christianity lie without any connection side by side'.

2.Ellul (1977:189) exhorts readers to develop a detailed literary analysis without mistaking symbolic language for a secret code. In interpreting the symbolic there are two main approaches, the 'steno' interpretation (one-to-one relation, that is, a single reality polysemic, hence its strength (Richard 2000:18).

3.Frilingos (2004:1-7) reads Revelation within the framework of its cultural milieu, attending to themes related to Greek romance, the Roman arena with general spectacles of gladiators and monsters. It is as if Revelation portrayed a dramatic representation of clashes and battles for an audience avid for the morbid. 


\section{Revelation: More than words}

John transmits his message via images. It is a book of visions and auditions. ${ }^{4}$ When the word is predominant, texts show little freedom and tend to be less open to different possibilities of interpretation, but when the image predominates, texts are evocative although still framed by the propositions within the text (Humphrey 2007:28).

Revelation is a dynamic iconography where images reveal their intrinsic logic and movement. An example will be useful. Revelation is contemporary with 4 Ezra, a Jewish apocalypse where war and apocalyptic militarism are squarely rejected. Perhaps the reason for it is the failed Jewish revolt (cf. Bauckham 1993:232). But if we compare 4 Ezra with Revelation - an apocalypse of clear Christian character - it is shocking to observe that Revelation does not renounce militaristic images and scenes of crude violence (as in Rv 19:11-21). In light of this, some have concluded that violence is 'necessary' when the goal is the extermination of Evil. However, Bauckham (1993:233) observes that the 'distinctive feature of Revelation seems to be, not its repudiation of apocalyptic militarism, but its lavish use of militaristic language in a nonmilitaristic sense' (original emphasis). We need to be aware of the function of this imagery and not mistake description for content. Although Revelation uses violent images, in essence its message reinterprets this setting because victory is won by absorbing violence and evil:

John's apocalyptic imagery achieves 'a symbolic transformation of the world', i.e. it changes his readers' perception of the situation in which they live and so enables them to behave differently in response to it. The imagery of holy war provides a most effective vehicle for this purpose because it highlights the issue: when the beast puts the martyrs to death, who is the real victor? The answer, in Revelation, depends on whether one sees the matter from an earthly or a heavenly perspective.

(Bauckham 1993:235)

And this, if I may insist, is accomplished mostly through its particular use of imagery.

\section{Choosing a concrete perspective}

Revelation is a message of judgement of present history, empathising with those who suffer. John, the recipient of the visions, is their 'brother and partner in affliction' ( $\operatorname{Rv} 1: 9)$. It is not a 'lukewarm' text; it takes sides with the powerless against the establishment. Its rhetoric aims at provoking the rejection of the false image of beneficence and justice that the Roman Empire presents, when the truth behind it all is corruption and evil-doing. Revelation's purpose is to 'dis-close' the immediate, what is perceived by the senses. John acts therefore as a social critic, and his message reveals 'things that are soon to occur'.

Revelation is the opposite of what we call ideology, which tries 'to cover up reality and aims to legitimise domination' (López Rosas \& Richard 2006:298). Therefore John's visions

4. Revelation contains 150+ allusions to 'seeing', 'hearing' and 'saying'; some of them combined 'I looked and saw'; 'I heard and saw'. Skagss and Doyle (2009:370) read combined: 'I lokked and saw', 'I heard and saw'. Skaggs and Doyle (2009:370) read Revelation in light of the 'seeing'/hearing' scheme: "This contrast is indeed clear to the reader, John hears some things, and sees others. Whereas the seeing describes the outward appearance, the hearing uncovers the inner reality, the spirit, the essence of what is seen' (original emphasis). are to be interpreted, contemplated and transformed into action. There is no hope unless the message is digested and the experience made concrete here and now. John writes with passion because the communities he addresses are easily accommodating to this ideology, the present evil system (cf. Thompson 1990:125). Who will reveal the truth?

\section{Film theory}

Biblical exegesis should make use of any discipline that can add new insights. I approach Revelation's dynamic iconography using the analogy of film theory, which works with four basic elements, (1) the selection of parts of the grand narrative (diegesis), that is, the story, (2) camera movements (including angles, sequence, distance, framing, perspective, and so on), (3) montage and (4) sound track. Revelation shares in these elements, John centres on (1) events that will soon occur, (2) he narrates the events from a particular point of view, sometimes focusing on the earthly, then on the heavenly, (3) John has arranged events in sequences of seven, in order to advance the story and (4) the visual is immersed in the aural: the letter is to be read in public, and the aural expands on the sense the images carry.

John wants to communicate a revelation concerning Jesus Christ that he has received from God through a messenger. It is like a good book transformed into a film, where the director sits behind the camera and tells the story from a particular point of view ( $\operatorname{Rv} 1: 9)$. Nevertheless, the director too will eventually be in front of the camera, for he or she are part of the story. We are not dealing with 'objective' history - as if that were possible. John acts as the prophets of old, eating the message, sweet at first - sour later on - as sign of participation in the drama of history that enfolds before us (Rv 10:8-10).

\section{The context: Vision of the celestial court}

John starts from a vantage point: the celestial court (Rv 1:4-6), where the 'ruler of kings on earth' reigns ( $R v$ 1:5). Despite the desperate situation the audience experiences, the message is clear: God is in control. John himself is exiled on a faraway island, powerless, but aware that he is under a government $\left[\beta \alpha \sigma \imath \lambda \varepsilon^{\prime} \alpha\right]$ which transcends the political power of the day. ${ }^{5}$



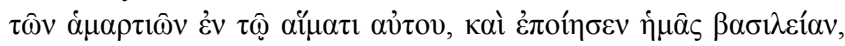

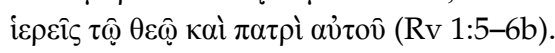

Revelation provides encouragement and hope to Christfollowing communities that struggle to be faithful in the midst of a system that threatens to swallow them. ${ }^{6}$ Revelation is prophecy that happens in the midst of the worship of the

5.In Revelation 1:9 John describes himself as not only 'sharing in the common

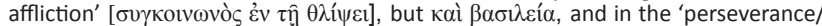
resistance' in Jesus. 6.The problems that plague the churches extend beyond a supposed state-
organised persecution against Christ-followers, and include local persecution organised persecution against Christ-followers, and include local persecution
(Rv 2:13), synagogue relations ( $\operatorname{Rv} 2: 9$ ), trust in wealth (3:17) and the dangers of accommodating to dominant culture (Koester 2009:7-9). 
community of faith $(\operatorname{Rv} 1: 1-8 ; 22: 6-21)$, and it is subversive because another Kyrios, instead of Caesar, is adored. That is

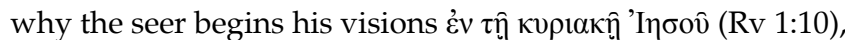
a clear sign that another Kyrios reigns. ${ }^{7}$

\section{The director's angle}

John wants to tell his story, but the diegesis (the grand narrative) is always bigger than that which he can capture with his lense. History belongs only to God, not to the political powers, the dragon, Satan or even the church. This adds further value to the term reve[a]l-ation: it describes the action by which we seek to dis-cover God's action in human history through Jesus Christ. His perspective is complex, as he juxtaposes planes and images to provide a more complete view of 'reality'. John seeks to capture both what is perceived by the senses, as well as that which escapes the sensory - the 'spiritual' - at once. 'History is not only what is seen, heard, felt or touched. What is most important is what cannot be seen' (Richard 2000:16).

\section{The medium: Vision-report}

The audience is assured of the (eschatological and present) blessing from God to those who 'read', 'hear' and 'keep' what is written therein. The medium is none other than the public reading of the prophecy $(\operatorname{Rv} 1: 3)$, where through the images, the audience is encouraged to keep the faith in the face of powerful imperial ideology. ${ }^{8}$

E.M.Humphrey (2007:15) affirms that Revelation is structured through vision-reports, a rare biblical Gattung which emerges at crucial moments. ${ }^{9}$ A vision-report is:

the revelation both of something that has been seen and heard in a first instance, and as something that can be transmitted as more than a recorded and remembered teaching [...]. The revelation thus involves both the sight of the glory of God in Jesus and the words that interpret what has been seen. This is in harmony with the broader Hebrew and Christian tradition, where God is depicted as communicating by both vision and audition; frequently the two are conjoined so that revealing a mystery is placed in the context of interpretive word or interpreted word is made vivid or enhanced by vision.

(Humphrey 2007:17-18)

And 'where we find vision-reports, we inevitably find argumentation, either explicit or implicit' (Humphrey 2007:18), because both word and image work in synergy in order to transform the audience. ${ }^{10}$

7.'Those outside the church worship the Beast of Roman imperial authority. For Beast worshippers, time is structured around the birth of Augustus and secondarily around the other emperors [...]. The system meshed well with the rhythms of life in the cities of Asia, but it fit John's calendar poorly' (Friesen 2001:158).

8.'Those first ancient auditors of the Apocalypse came together not merely to be informed, but to be transformed, to undergo a collective change in consciousness, an aspiration that makes modern individual and group reading practices trivia by comparison, with the possible exception of the reading of wills. Reading the Apocalypse aloud and hearing the Apocalypse read aloud, was effectual: through exhortations and exclamations, threats and thunder, the reading of the Apocalypse exhortations and exclamations, threats and thunder, the reading of the Apocalyps 1995:460).

9. Hanson (1980:1395-1427) speaks of dream-vision reports.

10.This is clear in the subtle play of words John carries in Revelation 1:1-12: кà



\section{Unceasing suffering: The souls under the altar}

From the outset, Revelation announces a higher government and a present victory, but suffering continues for the faithful. In Revelation's timeframe this seems to happen at once. How can the audience make sense of it? Maybe we can explain it by means of juxtaposed images. Soviet filmmaker Lev Kuleshov (1920s) applied 'shot and cut experiments', constructing spatial relations by eliminating establishing shots. 'The most famous of these involved the cutting of neutral shots of an actor's face with other shots (variously reported as shots of soup, nature scenes, a dead woman, a baby). The reported results was that the audience immediately assumed not only that the actor's expression changed but also that the actor was reacting to things present in the same space as himself' (Bordwell \& Thompson 1997:281). Brewer (1952:228) explains it in reference to the characteristic features of Graeco-Roman theatre where different parts of the drama were played at once: the main stage (or orchestra) where the story took place, and above it, a platform (the theologium) where the gods appeared if necessary. Let us take a closer look at the subject.

\section{The lion, the scroll and the lamb}

After the seven letters, John hears a voice like a trumpet sound, which signals a change in scenario (Rv 4:1). He looks toward the heavenly throne and sees one seated on it, with a sealed scroll in his right hand, symbolising that history's meaning is not immediately accessible for humanity ( $\operatorname{Rv} 4: 2)$. John looks around but nobody is able to open its seals and he cries $(\operatorname{Rv} 5: 4)$, for he represents the faithful community who struggles to understand the reason for this suffering and oppression (López Rosas \& Richard 2006:325).

Then one of the elders announces one who is worthy to open the scroll and the seven seals: the Lion of Judah, the Root of David (Rv 5:5). This announcement represents a climax in the story, an end to their suffering. But when John takes a closer look he sees only a lamb [ápvíov] as though slain ( $\operatorname{Rv} 5: 6$; cf. 1:18). This is a clear example of a superposition of images: if the lion symbolises conquest, the lamb refers to sacrificial death. Together, though, they convey the idea of 'conquest of the cosmos through sacrifice', the creation of a new symbol (Bauckham 1998:184). John refuses to homogenise these two images and leaves us with an unresolved and startling juxtaposition:

The result is a complete redefinition of omnipotence. Strength and authority belong not to the one who has practiced violence but rather to the one upon whom violence has been inflicted.

(Friesen 2001:200)

The lamb then receives universal proskynesis ( $\operatorname{Rv} 5: 13-14)$, for he represents victory won by suffering, which will reappear in Revelation 19:11-16, when the knight dressed in white conquers, his robes crimson-stained from his own blood, prior to battle.

But what is the reason for this paradox, this clashing of images? What is John trying to effect on the audience? Perhaps we need to retain in our minds both the art of 
filmmaking as well as the theatrical staging Brewer alluded to earlier. A common feature of Graeco-Roman dramas was a sort of author's cop-out, where an outside force decided a seemingly unsolvable problem in an extremely unlikely (and most anticlimactic) way. This recourse was known as deus ex machina (literary 'god out of the machine') and provided a way out of the impasse the situation had reached as the figure of a particular god intervened in the play, lowered by a crane. However, John plays a very different game here. This lion or lamb figure had never left the scene, for Revelation makes clear that he walks amidst the churches ( $\operatorname{Rv} 1: 13$ ). Could it be that John is playing against this accepted deus ex machina recourse, where the gods only intervened as it fit them so as to satisfy their own wishes? Rather than acting from above and outside to solve humanity's drama, this Jesus - lion and lamb - is he 'who was and who is and who is to come' $(\operatorname{Rv} 1: 8 ; 4: 8 ; 21: 6 ; 22.13)$. He has never abandoned history, but humanity's focus has been too limited all along. Immersed in our own struggle to survive, we lost sight of his presence and consequently surrendered to ideology.

\section{History unfolds: The seals}

Only one is worthy to open the seals. ${ }^{11}$ His revelation is both judgement and call to repentance. Those who submit to this present and perverted version of history suffer the voracity of the Empire and the elites, but equally, those who resist it suffer as witnesses or martyrs. The one worthy is


$\operatorname{Rv} 1: 5 ; 3: 14 ; 6: 10 ; 19: 11)$. Truth and falsehood are part of the seer's reality, but only the true witness is willing to conquer through unveiling the truth by his sacrifice. John's images communicate an alternative reading scenario: the true one.

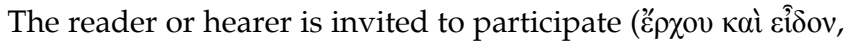
$\operatorname{Rv} 6: 1,3,5,7)$ in this un-veiling. The first four seals represent the true story about the violence and decay of the Roman Empire. The present system is powerful, but its authority is

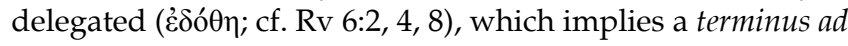
quem.

This brings us to the crux of the passage, which is also the crux of the interpretation of the whole book. At a first reading the account of the breaking of the seals leaves us with a sense of anticlimax. The choirs of heaven have sung their new song to acclaim a new act of God and to prepare us for the new revelation we can expect when the seals of the scroll are broken. Then on to the stage of history come only four horsemen representing disasters as old as the human race. Is this all that we are to receive from the regnant Christ? Has he after all nothing new to disclose, nothing new to achieve?

(Caird 1984:82)

But John has already answered this. The lamb represents power in the midst of suffering, the paradox of the seemingly weak that conquers all. Part of that victory is to expose history, occulted as it is by layers of ideology and false appearances.

\section{The fifth seal: The absence of God?}

Those dead because of the testimony call on God for justice.

11.Three reasons make him worthy (Rv 5:9-10), (1) he was slain, (2) by his blood he ransomed humanity and (3) he has made them a kingdom.

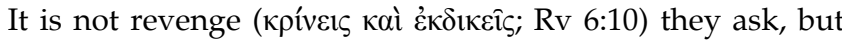
to be heard here and now. They embody the 'faithful witness'


because 'the utopia of Revelation is the kingdom of God, which is not construed at the end of history, but beyond oppression and death, in the midst of our story' (López Rosas \& Richard 2006:298). And these who cry are not dead, for John sees the 'souls' [ $\psi v \chi \alpha$ ćs] under the altar $(\operatorname{Rv} 6: 9) .{ }^{12}$ The altar


but the reference is nevertheless to the prayers of the saints that will soon be answered, when their number is completed (Rv 8:35). God's answer is not yet fully accomplished, but it will be sung once more in the worship of the community (Rv 19:2). But, are the martyrs reclaiming Christ's parousia? According to Revelation Jesus has never abandoned history. As López Rosas and Richard (2006:305) affirm: 'Revelation is not centred on the second coming of Christ, but on his glorious manifestation now in the historic present of the community.' Therefore, what the suffering community demands is that he manifest himself. The scene, though, reflects much tension. How can there be consolation when vindication is not nigh? The answer is that God is true to his particular way of acting. The only way to strip the powers is through ultimate selfgiving. The martyrs do not conquer due to their faithfulness but on account of their participation in Christ's victory. These have not died in vain; they are truly alive, because they belong to a different realm, and are promised the obliteration of pain and suffering because the Lamb is also the good shepherd (Rv 7:15-17). Bauckham (1993) refers to the delay of their vindication:

The tradition John has used in 6:9-11 did not explain why this should be, other than to appeal to the predetermined plan of God. But in the rest of his work John goes on to share the prophetic revelation which has been given to him as to the meaning of his delay. It is not just that there is an arbitrary decreed quota of martyrs to be completed. It is so that the witness of the martyrs may play a key role in God's purpose of establishing his universal kingdom.

(Bauckham 1993:56)

The text displays a profound lesson via images: God's apparent delay is not the absence of power, but the way God acts in history. We must not therefore mistake patience for weakness. This is the paradox of God's power, which promises the restoration of the entire universe in due course. It is similar to the gospel story where a measure of leaven ends up transforming the whole lump. The martyrs are the first ones to experience the power of leaven, although they have to wait yet a little longer before the transformation is complete (Rv 21:4-5). In the interim, so that the community of the faithful may be encouraged, they are given a glimpse of what happens 'offstage'. The power of the public reading of Revelation is this: that what takes place offstage is now placed in the spotlight.

The sixth seal is confirmation of God's power: judgement and revelation for the nations at one and the same time (6:12-17). ${ }^{13}$ John chooses now to focus on a new scene: the

12.'Souls' does not refer to an incorporeal life-state or to life after death, but as the 'totality of life' (Pikaza 1999:98).

13.The inclusive description of Revelation 6:15 (kings, great men, generals, rich and strong, slave and free) may be the content of what the martyrs call those who 'dwell upon the earth', for whom present evil structures are what they call 'home'. 
battle on earth still rages and the vision takes us now to the worship of the community in front of the throne. There are 144000 that worship God and the Lamb, accompanied by a multitude which cannot be numbered. It is a calming scene: even the winds remain motionless $(\operatorname{Rv} 7: 1)$. The contest is not a battle amongst equals (viz. God - Satan), for God is in perfect control of affairs. The great and urgent question can still be heard: is God near? The seventh seal begins with silence for about half an hour ( $\operatorname{Rv} 8: 1)$. It is God's silence, a profound experience the community undergoes. God has heard the cries of his faithful.

\section{Conclusion}

It is fair to conclude that Revelation is the gospel in nuce. Though Luther could not find Christ amidst its pages, we can assuredly affirm that Revelation 'breathes' Christ through its imagery. The victory of the Lamb completely transforms history, although at present it may be seen in the hands of the Empire. ${ }^{14}$

Physicist Archimedes of Syracuse (3rd century BC) had affirmed: 'give me a fulcrum and I shall move the world' [ $\Delta \mathrm{os}$ Mor Поу $\Sigma$ T $\Omega$ KaI Kins ThN $\Gamma$ HN]. Likewise, the life, death and resurrection of Jesus become the fulcrum - not the lever - by which the cosmos receives a new opportunity..$^{15}$ If in the first part of the book evil seems all-pervasive, in the last chapters there is no sign of its existence. The resurrection of Christ marks the end of the world and inaugurates the new world as God wanted (Prévost 1994:100), a replay of the gospel story (Contreras Molina 1991:346). From this point of view John communicates that history is ultimately written by those who conquer, by what appears weak. ${ }^{16}$ Spanish writer V. Blasco Ibáñez wrote in his acclaimed The four horsemen of the Apocalypse (1916), during World War I, that 'the beast never dies, it only hides waiting for the opportune moment' (García Landa 2004:1), but Revelation announces the complete obliteration of evil: it will never more appear in the scene.

The beginning of the book ( $\operatorname{Rv} 1: 1)$ speaks the revelation of Jesus the Messiah. The story wants to encourage those who are about to give up; but encouragement will not be enough unless Jesus strips the powers of their lies. The faithful are not to be deceived by their ideology; they need to come out of them $(\operatorname{Rv} 18: 4)$. There is no chance of sharing in God's victory ( Rv 3:21) unless one renounces one's own life.

John concludes with a strong warning against adding to the words of the prophecy ( $\operatorname{Rv} 22: 18-19)$, because John has communicated what he really wanted to express. His aim is

14.'Once the center is understood, the Lamb is the definition of reality, slain from the foundation of the World and living forever. The Beast is a blasphemous imitation bound for destruction' (Friesen (2001:164).

15.'The throne of God and of the lamb descends to humanity with the new Jerusalem [...] The transcendent cohabits with the contingent, resulting in the unimaginable: walls with gates that are never closed, day without night, land without sea, habitation without temples, splendour without poverty kings who offer their glory to the Creator, and nations that walk in the light of God's glory' (Friesen 2001:164).

16.'Irony is natural to an apocalypse, for the basic intent of the genre is to remove the veil of ordinary perception, to see what is happening behind the scenes. This hidden action is often the opposite of ordinary perception. In John's cultural world, Rome rules; in John's story world, Jesus rules. Everyone sees this irony. But world, Rome rules; in John's story world, Jesus rules. Everyone sees this irony. But
John destabilizes this world with a double irony, for Jesus rules only through his suffering' (Barr 2009:28-29). the transformation of the community's way of thinking in the midst of history, and he bases his appeal on imagery's evocative power. We are no longer spectators but participants in the story. After all, it is a book that displays a peculiar abhorrence for ambiguity, little patient with the lukewarm ( Rv 3:15). The blessing is not in discerning every detail of the events, but in keeping its message.

\section{Acknowledgement}

This article was written in honour of Andries G. Van Aarde. I had the privilege of meeting Professor Andries G. van Aarde by sheer chance - if such a thing really exists - in 2004. Our family had moved to South Africa, and my wife, a Pretorian-turned-missionary to the Spaniards, encouraged me to visit the University of Pretoria and enrol in some courses during our year-long stay. There I had an interview with Professor Van Aarde. His contagious and warm spirit quickly convinced me to enrol in the PhD programme at the University of Pretoria and to pursue excellence in all I wanted to accomplish. Professor Van Aarde impressed me with his deep desire to actualise the Scriptures in today's world. It is with gratitude that I dedicate this article, which represents a creative search for reading scriptures both with passion and through new perspectives, to Professor Van Aarde.

\section{References}

Barr, D.R., 2009, 'John's ironic empire', Interpretation 63(1), 20-30.

Bauckham, R., 1993, The theology of the Book of Revelation, Cambridge University Press, Cambridge, UK.

Bauckham, R., 1998, The climax of prophecy, T\&T Clark, London/New York.

Bordwell, D. \& Thompson, K., 1997, Film art. An introduction, 5th edn., McGraw-Hill, New York.

Brewer, R.R., 1952, 'Revelation 4:6 and translations thereof', Journal of Biblical Literature 71(4), 227-231. doi:10.2307/3261614

Caird, G.B., 1984, The revelation of St John the apostle, 2nd edn., A \& C Black, London.

Callahan, A.D., 1995, 'The language of apocalypse', The Harvard Theological Review 88(4), 453-470.

Contreras Molina, F., 1991, El señor de la vida. Lectura cristológica del Apocalipsis [The Lord of life. Christological reading of the Apocalypse], Sígueme, Salamanca. Ellul, J., 1977, Apocalypse: The Book of Revelation, Seabury, New York.

Friesen, S.J., 2001, Imperial cults and the apocalypse of John. Reading Revelation in the ruins, Oxford University Press, Oxford. doi:10.1093/0195131533.001.0001

Frilingos, C.H., 2004, Spectacles of empire. Monsters, martyrs, and the Book of Revelation, University of Pennsylvania Press, Philadelphia.

García Landa, J.Á., 1985, Los Cuatro Jinetes del Apocalipsis de Vicente Blasco Ibáñez [The Four Horseman of the Apocalypse by Vicente Blasco lbáñez], 1-4, viewed 10 November 2009, from www.unizar.es/departamentos/filología_inglesa.

Hanson, J.S., 1980, 'Dreams and visions in the Greco-Roman world and early Christianity', Aufstieg und Niedergang der römischen Welt 2.23.2, 1395-1427.

Holtzmann, H.J., [1896-1897] 1991, Lehrbuch der Neutestamentlichen Theologie [Text book of the New Testament Theology], 2 nd rev. edn., 2 vols, Mohr Siebeck, Tübingen.

Humphrey, E.M., 2007, And I turned to see the voice. The rhetoric of vision in the New Testament, Baker Academic, Grand Rapids.

Koester, C.R., 2009, 'Revelation's visionary challenge to ordinary empire', Interpretation 63(1), 5-18.

López Rosas, R. \& Richard, P., 2006, Evangelio de Juan y Apocalipsis de san Juan [Gospel of John and Revelation of St. John], Verbo Divino, Estella.

Pikaza, X., 1999, Apocalipsis [Apocalypse], Verbo Divino, Estella.

Prévost, J.-P., 1994, Para leer el Apocalipsis [To read the Apocalypse], Verbo Divino, Estella.

Richard, P., 2000, 'Apocalipsis: Reconstrucción de la esperanza [Apocalypse: Reconstruction of hope]', Reseña Bíblica 27, 13-20.

Shaw, G.B., 1933, The adventures of the black girl in her search for God, Dodd \& Mead, New York.

Skaggs, R. \& Doyle, T., 2009, 'Lion/Lamb in Revelation', Currents in Biblical Research 7(3), 362-375. doi:10.1177/1476993X09104458

Thompson, L.L., 1990, The Book of Revelation. Apocalypse and empire, Oxford University Press, New York/Oxford. 